\title{
Angiogenesis as a target in rheumatoid arthritis
}

\section{A E Koch}

Ann Rheum Dis 2003;62(Suppl II):ii60-ii67

A ngiogenesis, the growth of new blood vessels, is important in a variety of fibroproliferative disorders, such as diabetic retinopathy, psoriasis, tumour growth, and rheumatoid arthritis (RA). We and others have reviewed this subject recently. ${ }^{1-15}$ Blood vessel growth probably contributes to the proliferation of the inflammatory synovial pannus as well as to the ingress of inflammatory leucocytes into the synovial tissue. The process of angiogenesis is a fine tuned balance between angiogenesis induction and inhibition. In this article, I will review some of the current advances in the angiogenesis field, specifically focusing on understanding angiogenesis in RA (table 1).

\section{FIBROBLAST GROWTH FACTORS}

Among the earliest identified angiogenic factors were the fibroblast growth factors. Folkman and colleagues took advantage of the observation that mast cells, which secrete heparin, were often found in proximity to blood vessels. ${ }^{16}$ Hence, the ability to bind heparin was used as the first method of isolating angiogenic factors. Recently Yamashita and coworkers found that the synovium of patients with RA and joints from rats with adjuvant induced arthritis (AIA) contained increased amounts of fibroblast growth factor-2 (FGF-2). ${ }^{17}$ Moreover, a Sendai virus containing the FGF-2 gene resulted in worse arthritis in rat AIA, but had no effect on normal joints. Hence, it seems that FGF-2 is important in worsening the progression of experimental arthritis rather than being important in the initiation stage of disease.

\section{VASCULAR ENDOTHELIAL GROWTH FACTOR (VEGF)}

An angiogenic mediator which has attracted much attention recently is VEGF, which is an endothelial selective growth factor. $^{18}$ VEGF induces vascular permeability as well. In human RA, several groups have described VEGF in the joints and serum of patients. ${ }^{19-28}$ In the control of VEGF secretion in the RA joint, not only do cytokines like interleukin 1 (ILl) and tumour necrosis factor $\alpha(\mathrm{TNF} \alpha)$ induce fibroblast expression of VEGF but so also does engagement of the CD40 ligand. ${ }^{29}{ }^{30}$ VEGF induces endothelial decay accelerating factor, which is

\begin{tabular}{l} 
Table 1 Some angiogenesis inducers relevant to RA \\
\hline Cytokines: \\
Fibroblast growth factors such as FGF-2 \\
VEGF \\
TGF $\beta$ \\
TNF $\alpha$ \\
Chemokines such as IL8, fractalkine \\
IL18 \\
IL1 \\
Soluble adhesion molecules such as soluble E-selectin, soluble \\
VCAM-1 \\
Glycoconjugates, such as the soluble 4A1 1 antigen \\
Soluble CD 146 \\
The angiopoietin-Tie system
\end{tabular}

cytoprotective against activated complement and may regulate endothelial proliferation and angiogenesis. ${ }^{31}$

VEGF binds to VEGF-Rl/Flt- 1 and VEGF-R2/Flk-1/KDR. Recently VEGF-C and VEGF-D have been described. In contrast with VEGF, VEGF-C is inducible by ILl/TNF $\alpha$, but not hypoxia. VEGF-C is chemotactic for monocytes and mediates angiogenesis and lymphangiogenesis (the growth of lymphatic vessels in mouse skin). VEGF-C is the ligand for the FMS-like tyrosine kinase receptor Flt-4 (VEGF-R3). VEGF-C is strongly expressed in RA synovial lining, pericytes, and vascular smooth muscle. ${ }^{32}$ VEGF-D binds VEGF-R2 and VEGF-R3 on lymphatic endothelial cells and is angiogenic. VEGF-D expression is not abundant in RA synovial tissue. ${ }^{32}$ In the same study both VEGF-R2 and -R3 were expressed in RA synovium on blood vessels. Whereas VEGF-R3 has been considered to be relatively specific as a marker for lymphatic vessels in adult tissue, the significance of RA synovial endothelial VEGF-R3 expression is unclear. One may speculate that because synovial tissue contains fenestrated blood vessels, which play a part in nutrition of the avascular hyaline articular cartilage, VEGF-R3 may potentially be involved in the maintenance of fenestrations and formation of joint synovial fluid.

A number of drugs used to treat RA may modulate VEGF production. For instance, cyclosporin treatment of RA synovial fibroblasts exposed to transforming growth factor $\beta$ (TGF $\beta$ ) results in decreased production of VEGF. ${ }^{33}$ In patients with RA treated with anti-TNF $\alpha$, vascular deactivation occurs so that serum levels of VEGF fall along with clinical improvement. ${ }^{34}$ Experimentally, modulation of a VEGF receptor through a VEGF-Rl Fc molecule suppressed RA synovial endothelial proliferation..$^{35}$ The angiogenesis inhibitor TNP-470, a derivative of the fungal product fumigillin, suppressed angiogenesis and RA synovial tissue volume in a human RA synovial tissue-severe combined immunodeficient (SCID) mouse chimera, in which human RA synovium is allowed to implant and thrive in these. ${ }^{36}$ These studies suggest that drugs or potential future therapeutic agents may be useful in their ability to target VEGF.

The role of VEGF has been examined in several animal arthritis models also. Anti-VEGF reduces arthritis onset and severity as well as joint angiogenesis in mouse collagen induced arthritis (CIA). ${ }^{37}{ }^{38}$ Preventative administration of TNP-470 in spontaneous models of RA in KRN $\times$ NOD mice results in attenuated arthritis and decreased serum VEGF. ${ }^{39}$ Other therapeutic approaches have been to target the VEGF receptor Flt-1. Hence, Miotla and coworkers and Luttun and coworkers have shown that anti-Flt-1 or soluble Flt-1 reduced

Abbreviations: AIA, adjuvant induced arthritis; Ang, angiopoietin; bFGF, basic fibroblast growth factor; $\mathrm{ClA}$, collagen induced arthritis; COX, cyclo-oxygenase; FGF, fibroblast growth factor; HIF, hypoxia inducible factor; IL, interleukin; $\mathrm{mAb}$, monoclonal antibody; OA, osteoarthritis; RA, rheumatoid arthritis; SCID, severe combined immunodeficient; SDF, stem cell derived factor; TGF $\beta$, transforming growth factor $\beta$; TNF $\alpha$, tumour necrosis factor $\alpha$; VCAM, vascular cell adhesion molecule; VEGF, vascular endothelial growth factor 


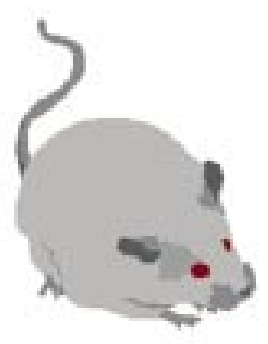

Mouse

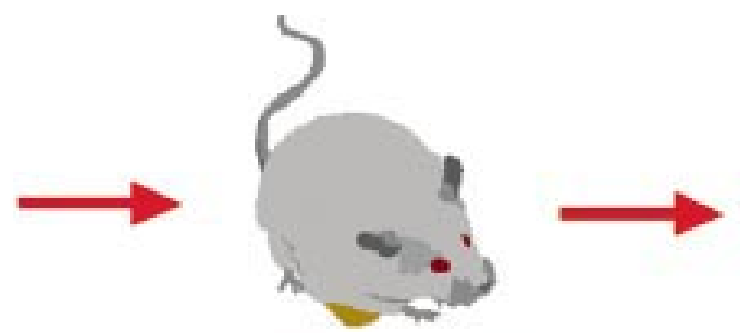

Figure 1 Schematic diagram of the Matrigel angiogenesis in vivo assay.

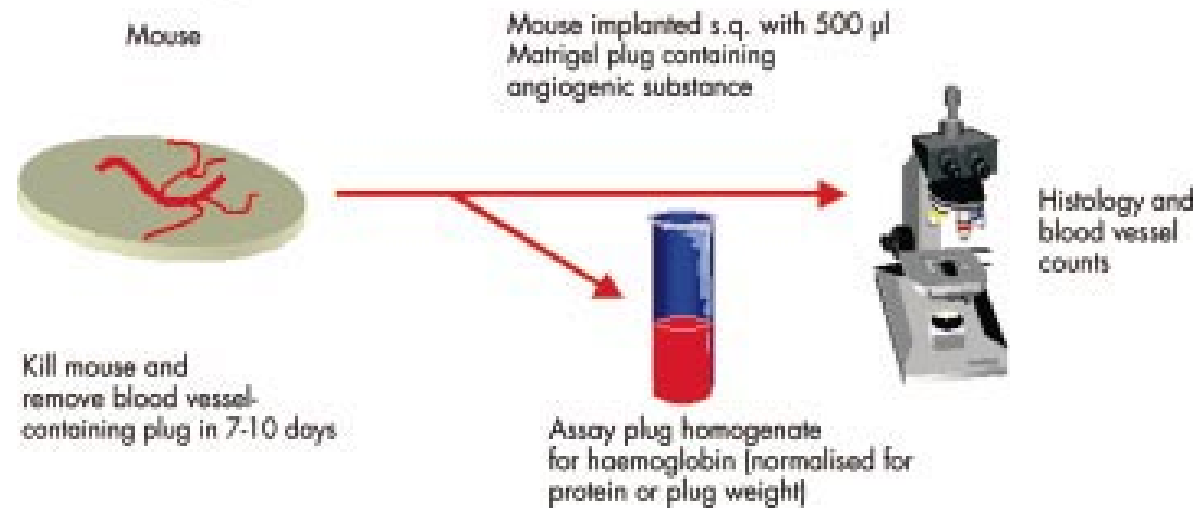

synovial angiogenesis and arthritis. ${ }^{40}{ }^{41}$ Administration of the fungal derivative TNP-470 in rat arthritis leads to attenuated arthritis and serum VEGF production. ${ }^{36}$

\section{ROLE OF HYPOXIA INDUCIBLE FACTOR (HIF) IN ARTHRITIS}

VEGF is inducible by hypoxia, which may occur in the inflamed joint. ${ }^{22}{ }^{29}$ HIF-1, which comprises HIF-1 $\alpha$, and hydroxycarbon nuclear translocator (ARNT) controls many transcriptional responses to hypoxia by binding to hypoxia response elements of VEGF and other target genes. ${ }^{42}$ Hypoxia increases VEGF production by RA synovial fibroblasts, but this production is even more marked in the presence of inflammatory cytokines such as ILl and TGF $\beta{ }^{29}$ These findings suggest that inflammatory cytokines augment the production of VEGF in the face of a hypoxic joint. Recently, Hollander and coworkers have identified HIF-l $\alpha$ in RA synovial tissue, predominantly in macrophages. ${ }^{43}$ Moreover, Cramer and colleagues showed that when the HIF- $1 \alpha$ gene was deleted in mice, arthritis was attenuated in the $\mathrm{KRN} \times \mathrm{NOD}$ mouse arthritis model. ${ }^{44}$

HIF is thus becoming increasingly important in the pathogenesis of RA.

\section{IL18 AS AN ANGIOGENIC MEDIATOR}

Clearly cytokines such as TNF $\alpha$ and VEGF are important angiogenic mediators in RA. We have recently defined a new cytokine, IL18, in the induction of RA synovial angiogenesis. ${ }^{45}$ IL18 is a potent inducer of endothelial chemotaxis in vitro and angiogenesis in vivo in the Matrigel plug assay and sponge angiogenesis assay in rodents. In the Matrigel plug assay (fig 1), the matrix protein Matrigel containing an angiogenic mediator is implanted in mice. After 7-10 days the plugs are harvested and blood vessel growth quantified by histology or assay of plug homogenate for haemoglobin, which is proportional to the number of blood vessels. Immunodepletion of ILl8 from RA synovial fluids resulted in reduced endothelial migration in vitro, suggesting that IL18 is important in RA mediated angiogenesis. IL18 appears to act on endothelium through an $\alpha v \beta 3$ mediated mechanism (see below).

\section{CHEMOKINES AS ANGIOGENIC MEDIATORS}

Among other important mediators of angiogenesis are chemokines. Most chemokines are low molecular weight (8-10 kDa) proteins, which are predominantly known for their ability to recruit leucocytes. Chemokines are divided into the $\mathrm{C}-\mathrm{X}-\mathrm{C}, \mathrm{CC}$, and $\mathrm{C}-\mathrm{X}_{3}-\mathrm{C}$ families based on the presence or absence of an amino acid, $X$, between a pair of cysteine residues near the amino terminus of the protein . In collaboration with Dr Robert Strieter, Peter Polverini, and Steve Kunkel, our group found that monocyte/macrophage derived IL8, a prototype of the C-X-C chemokine subfamily, was angiogenic. ${ }^{46}$ This factor appeared important in that synovial tissue macrophagederived chemotactic activity for endothelial cells in vitro and angiogenesis in vivo was significantly decreased if IL8 was immunodepleted.

In general, chemokines like IL8, of the C-X-C class containing the amino acid E-L-R motif are angiogenic, while those lacking this motif are angiostatic. ${ }^{47}$ Exceptions to this generalisation exist in that the $\mathrm{C}-\mathrm{X}-\mathrm{C}$ chemokine stem cell derived factor-1 (SDF-1), which lacks the E-L-R motif, is angiogenic. ${ }^{48}$ Hitchon and colleagues have recently shown that hypoxia up regulates both VEGF and SDF-1 expression in RA synovial fibroblasts. ${ }^{49}$ Clearly chemokines, such as SDF-1, also recruit leucocytes to the inflamed RA synovium ${ }^{50} 51$

We have shown that fractalkine is the first chemokine described of the $\mathrm{CX}_{3} \mathrm{C}$ class to mediate angiogenesis. ${ }^{52}$ Fractalkine is so called for its fractal geometry and is the sole member of the $\mathrm{CX}_{3} \mathrm{C}$ class of chemokines. ${ }^{53}$ It contains a chemokine motif on top of a mucin-like stick, the so-called chemokine on a stick. ${ }^{53}$ Fractalkine is a unique chemokine in that it can also act as an adhesion molecule when cell bound. Fractalkine induces endothelial tube formation on the matrix Matrigel in vitro. Similarly, fractalkine induces angiogenesis in Matrigel plugs implanted in mice in vivo. When fractalkine is immunodepleted from RA synovial fluids, the ability of these synovial fluids to chemoattract endothelial cells, a facet of the angiogenic response in vitro, is decreased. Hence, chemokines are probable contributors to RA angiogenic activity.

\section{MECHANISM OF ACTION OF SOME ANGIOGENIC CYTOKINES: THROUGH ADHESION MOLECULES LIKE INTEGRINS}

The invasion, migration, and proliferation of endothelial cells is regulated, at least in part, by the integrin family of cell adhesion molecules. $\alpha v \beta 3$ is minimally, if at all, expressed on resting or normal blood vessels but is highly expressed in RA synovial blood vessels. ${ }^{54}$ Some angiogenic factors like basic 
fibroblast growth factor (bFGF), TNF $\alpha$, and ILl8 may act through $\alpha v \beta 3$ integrins. ${ }^{55}$ VEGF or TGF $\alpha$ appear to act through an $\alpha v \beta 5$ integrin mechanism using protein kinase $C$. This may turn out not to be a main mode of action of VEGFs in RA because $\alpha v \beta 5$ integrin has been reported to be expressed in normal and osteoarthritic (OA) synovial tissue, but not RA synovial tissue. ${ }^{56}$ None the less, the mechanisms by which some of these cytokines act to promote angiogenesis are rapidly becoming identified.

$\alpha v \beta 3$ has been targeted using animal arthritis models. Storgard and colleagues showed that anti- $\alpha v \beta 3$ integrin decreased synovial angiogenesis in a rabbit arthritis model. ${ }^{57}$ An oral non-peptide $\alpha v \beta 3$ antagonist ameliorated arthritis in rats. ${ }^{58}$ Finally, a proaptotic $\alpha \mathrm{v} \beta 3$ antagonist, composed of an RGD peptide linked to a heptapeptide dimer, is therapeutic in mouse CIA and selectively homes to mouse arthritic synovium compared with normal synovium and with control organ endothelium. ${ }^{59}$ Clearly, this integrin is a promising target for angiogenesis inhibition.

\section{SOLUBLE ADHESION MOLECULES AS ANGIOGENIC MEDIATORS}

Endothelial cells express soluble adhesion molecules, particularly upon cytokine stimulation. Cellular adhesion molecules are shed from the cell surface and secreted. The function of these soluble adhesion molecules is unclear. Neidhardt, Gay, and colleagues have found that the new endothelial antigen CD146 (Mucl8), which is potentially involved in endothelialleucocyte adhesion, is increased in the soluble form in RA compared with OA synovial fluids. ${ }^{60}$

We have examined other soluble adhesion molecules. A prevailing paradigm was that these molecules might serve an anti-inflammatory role by binding leucocytes, thus preventing them from adhering to endothelium and entering inflamed tissues. We proposed the converse paradigm that these molecules may be proinflammatory in some cases. Our laboratory found that the cellular adhesion molecules soluble E-selectin and soluble vascular cell adhesion molecule-1 (VCAM-1) are angiogenic. ${ }^{59} 6162$ It is likely that activated cells in the synovial milieu, such as endothelial cells, bear E-selectin and VCAM-1, which they then shed into the synovial fluid. These soluble adhesion molecules then interact with vascular endothelial cells through sialyl $\mathrm{Le}^{\mathrm{x}}$ in the case of soluble E-selectin, and VLA-4, in the case of soluble VCAM-1 to mediate angiogenesis. ${ }^{59} 6162$ We have recently shown that soluble E-selectin acts on endothelial cells through an Src and phosphoinositol-3 kinase mediated pathway. ${ }^{62 a}$ Inhibition of these pathways by chemical inhibitors, as well as antisense oligodeoxynucleotides directed against these signalling molecules, inhibited angiogenesis in both in vitro and in vivo assays. Interestingly, patients with RA treated with monoclonal anti-TNF $\alpha$ have an element of endothelial deactivation, in which treatment reduces levels of soluble E-selectin. ${ }^{63}$ Hence, these findings may be important clinically in RA.

\section{GLYCOCONJUGATES AS ANGIOGENIC MEDIATORS}

We have described another new related angiogenic mediator in our laboratory. This antigen, termed $4 \mathrm{Al} 1$, is an endothelial selective, cytokine inducible, endothelial angiogenic antigen ${ }^{64}$ We first raised monoclonal antibody (mAb) $4 \mathrm{All}$ by immunising mice with isolated adherent cells from human RA synovial tissue. The mAb we produced recognised endothelium in the synovium, thymus, skin, and lymph node selectively, perhaps suggesting a role in cell homing to these regions. Moreover, the mAb was endothelial selective, recognising endothelium and keratinocytes only. This antigen is up regulated in RA compared with normal synovial tissue and is rapidly cytokine inducible in vitro, being stored in cytoplasmic vesicles and up regulated on the cell surface within 5-20 minutes of contact with cytokines. We have obtained a

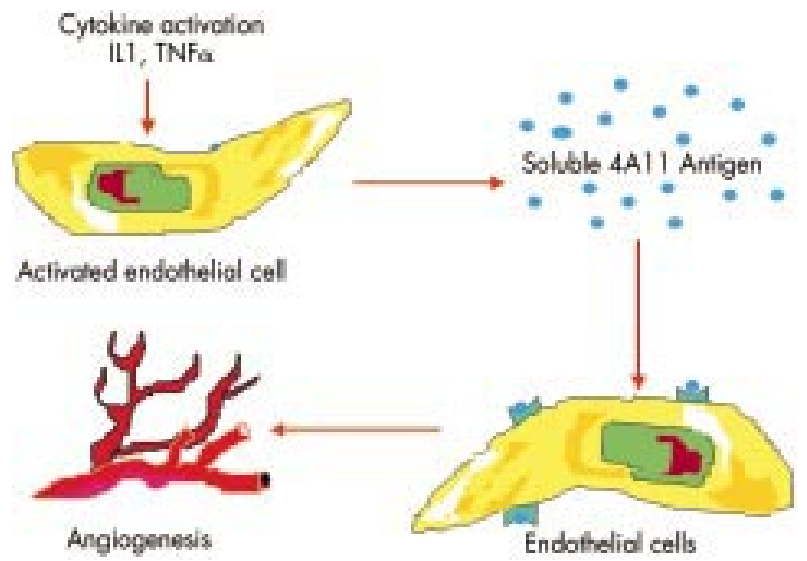

Figure 2 Suggested mechanism of the soluble $4 \mathrm{~A} 11$ antigen $\left(\mathrm{Le}^{\mathrm{y}} / \mathrm{H}\right)$. Endothelial cells are activated by inflammatory mediators to produce the $4 \mathrm{Al} 1$ antigen, which is then secreted to mediate angiogenesis in adjacent endothelial cells. This is the same paradigm for soluble molecules such as CD146, soluble E-selectin, or soluble VCAM-1.

partial structure of the antigen recognised by mAb 4All. The $\mathrm{mAb}$ detects Lewis -6 and H-5-2 antigens $\left(\operatorname{Le}^{\mathrm{y}} / \mathrm{H}\right)$. These structures are mainly recognised for their function as blood group antigens. Interestingly, these antigens are structurally related to the E-selectin ligand sialyl Lewis ${ }^{x}$. Because of the angiogenic properties of soluble E-selectin, we suggested these endothelial antigens were released by activated endothelium and induced angiogenesis (fig 2). Glucose analogues of these molecules or the glycolipids themselves induced a potent endothelial chemotactic response. Moreover, the glucose analogues are angiogenic in vivo in the corneal bioassays. mAb $4 \mathrm{All}$ abrogated the angiogenic responses. We reasoned that if these molecules mediated angiogenesis, they might be detected in clinical samples from patients with RA. We found that soluble 4All antigen is increased in RA compared with OA serum and synovial fluid. These results describe a new endothelium-selective antigen that functions as an angiogenic mediator. As with the E-selectin and VCAM-1, it is likely that endothelial cells exposed to cytokines bear the 4All antigen, which is shed in the inflamed joint and mediates angiogenesis.

Glycoconjugates (glycoproteins/glycolipids) have been known for some time to constitute the chemical basis for several blood group systems in man and to act as adhesion molecules for microbial ligands. ${ }^{65}$ The importance of glycoconjugates in the induction of autoimmunity was recently emphasised by the finding that Helicobacter pylori, the micro-organism involved in gastritis, ulcers, adenocarcinoma, and lymphoma of the stomach, expresses $\mathrm{Le}^{\mathrm{y}} / \mathrm{Le}^{\mathrm{x}} / \mathrm{H}$, which is also found in gastric mucin. ${ }^{66}{ }^{67}$ Mice bearing hybridomas making $H$ pylori induced anti-Le antibodies developed gastritis, pointing to a mechanism by which $H$ pylori participates in molecular mimicry. Thus, antibodies directed against $H$ pylori $\mathrm{Le}^{y}$ result in gastritis through an autoimmune reaction directed against gastric mucin $\mathrm{Le}^{\mathrm{y}}$. In diseases such as RA the inciting agent is unknown. Thus, possibly, $\mathrm{Le}^{\mathrm{y}} / \mathrm{H}$ may also trigger a molecular mimicry immune reaction in inflammatory angiogenic sites such as RA.

One hypothesis suggests that while endothelium is quiescent for weeks or longer, endothelial cells must also require a mechanism of storage of preformed regulators of angiogenesis which can induce new capillary growth within hours in response to angiogenic stimuli, such as those found in a wound or an inflamed synovial tissue. ${ }^{68}$ Despite this hypothesis, with the possible exception of bFGF, examples have not been described for angiogenesis inducers. The rapid 
Table 2 Some angiogenesis inhibitors relevant to RA

Endogenous inhibitors:

Cartilage derived factor: troponin-1

IL4

ILIRa

Angiostatin

Endostatin

2-Methoxyoestradio

Exogenous inhibitors

Angiostatic steroids

Minocycline

Fumigillin

Chloroquine

Sulfapyridine

Methotrexate

Gold compounds

Penicillamine

Thiol-containing compounds targeting macrophage derived

angiogenic mediators

Thalidomide

TNF $\alpha$ inhibitors

Taxol

Cyclo-oxygenase-2 inhibitors

cell surface expression of $\mathrm{Le}^{\mathrm{y}} / \mathrm{H}$ may fit this paradigm. However, an alternative scenario for the regulation of angiogenesis by inducers and inhibitors may be that structural mimicry has a role. Hence, for instance, a search based on crystal structure showed that the angiogenic inhibitor endostatin was most homologous to the angiogenic mediator E-selectin. ${ }^{69}$ It is likely that in an RA joint $\mathrm{Le}^{\mathrm{y}} / \mathrm{H}$ may be stored for expedient use during times of active inflammation and subsequent angiogenesis.

\section{THE ANGIOPOIETIN-TIE SYSTEM}

Unlike VEGF, angiopoietin-1 (Ang-1) is not a mitogen for endothelium, nor does it induce endothelial tube formation in vitro. Instead, its pattern of expression in the vicinity of forming vessels suggests that it has a role in regulating the assembly of non-endothelial vessel wall components like vascular smooth muscle. ${ }^{70} 71$ This finding is strengthened by the observation of Suri and coworkers, who showed that mice deficient in Ang-1 exhibit abnormal vasculature where the principal defect is failure to recruit vascular smooth muscle cells. For instance, in the heart, this defect is manifest as poorly developed endocardium. ${ }^{72}$ In RA, we and Gravallese and coworkers have shown that Ang-1 is expressed in human RA synovium in lining cells, macrophages, fibroblasts, and endothelium. ${ }^{73}{ }^{74}$ Expression of Ang-l is higher in RA than in OA synovial tissue. ${ }^{73}$ TNF $\alpha$ can serve as a stimulus to induce Ang- 1 expression in RA synovial fibroblasts. ${ }^{74}$

Ang-2 counters the effects of Ang-1 by disrupting blood vessel formation in the developing embryo by antagonising Ang- 1 induced phosphorylation of the Tie-2 receptor, to which Ang- 1 and Ang-2 bind. Ang-2 is also up regulated in RA compared with OA synovial tissue. ${ }^{73}$

One of the most exciting findings described by Vikkula and coworkers, was the discovery that venous malformations in two human families could be mapped to the Tie- 2 receptor on endothelial cells, where a missense mutation results in an arginine to tryptophan substitution. ${ }^{75}$ Patients carrying this mutation develop vein-like structures that are deficient in the non-endothelial cells of the vessel wall; mainly they lack vascular smooth muscle cells, resulting in thin walled vessels Therefore, the Tie-2/Ang system seems to govern maturation and stabilisation of blood vessels.

Whereas Tie-2 binds both Ang- 1 and Ang-2, Tie- 1 is an orphan receptor. In our study, Tie-1 expression was found on about $75 \%$ of synovial endothelial cells in RA compared with only $3 \%$ of endothelial cells in OA synovium. ${ }^{73}$ Tie-1 expression

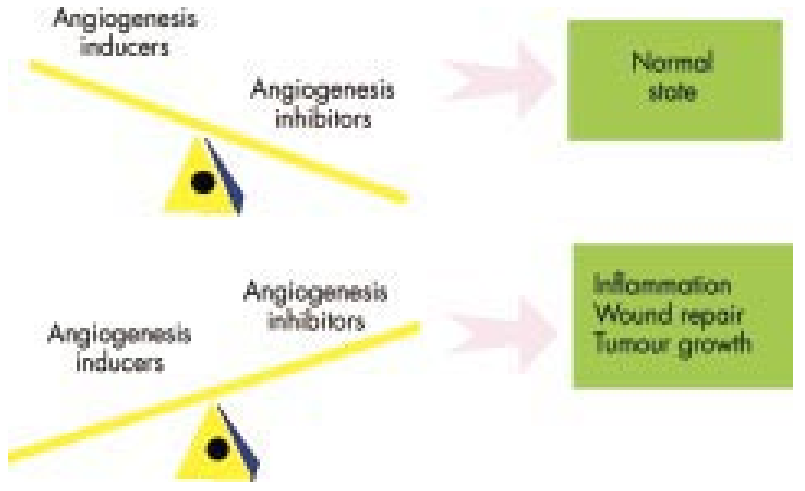

Figure 3 Balance of angiogenesis inducers and angiogenesis inhibitors in pathological disease states.

was not endothelial-specific, being expressed by a variety of other synovial cell types. ${ }^{73}{ }^{76}$ Like Tie-1, Tie-2 is also expressed on a variety of cells in the synovium and up regulated in RA compared with OA. ${ }^{73}{ }^{76}$ Hence, the delicate balance between members of the Ang and Tie families may contribute to vascular formation in RA (table 2).

\section{PARADIGM OF INHIBITORS RESIDING WITHIN LARGER PROTEINS}

Counterbalancing the angiogenesis inducers are the angiogenesis inhibitors (fig 3). One paradigm regarding angiogenesis inhibitors, mentioned above, is that angiostatic activity often resides in portions of larger common proteins, which may or may not themselves be angiostatic. ${ }^{68}$ Examples of this include many molecules thought to have a role in RA pathogenesis, like thrombospondin, fibronectin, and propeptides of type II collagen, platelet factor IV, and fragments of epidermal growth factor. Other mediators fitting this paradigm are the $29 \mathrm{kDa}$ fragment of fibronectin, the $16 \mathrm{kDa}$ fragment of prolactin, and angiostatin (a fragment of plasminogen), among others. ${ }^{77-80}$

\section{THROMBOSPONDIN AS AN ANGIOGENESIS INHIBITOR}

The idea that endothelium is quiescent for long periods of time and yet can be induced to sprout new capillaries in a matter of hours in response to an angiogenic stimulus, suggested that angiogenesis regulators might be stored for expedient use. The first indication of this paradigm was described by Bouck and coworkers, who found that a non-tumorigenic hamster cell line became tumorigenic with a mutation that inactivated a tumour suppressor gene. ${ }^{81}$ The inhibitory activity was found to be a fragment of the adhesive glycoprotein thrombospondin-1 whose expression was linked to the presence of a tumour suppressor gene. Thrombospondin appears to act by inducing endothelial cell apoptosis. ${ }^{82}$ Recently, metallospondins have been found using molecular techniques, and are even more potent angiogenic inhibitors than thrombospondin. ${ }^{83}$ We were unable to show that they inhibited arthritis or angiogenesis in a rat model of AIA. ${ }^{83} 84$

\section{ANGIOSTATIN AS AN ANGIOGENESIS INHIBITOR}

Another inhibitor of angiogenesis termed angiostatin has been identified in some very elegant studies by Dr Judah Folkman's group. ${ }^{785-89}$ This factor is a potent inhibitor of tumour growth. Angiostatin is a fragment of the clotting factor plasminogen. Plasminogen itself is not angiostatic. This factor acts by depleting energy required for blood vessel growth by binding ATP-synthase and induces endothelial cell apoptosis by activating focal adhesion kinase. ${ }^{88-90}$ Recently, angiostatin delivered through a retroviral vector, has been 
shown to reduce angiogenesis and CIA in mice. ${ }^{91}$ This study lends hope to the notion that endogenous angiostatic factors may be of therapeutic benefit in RA.

\section{ENDOSTATIN AS AN ANGIOGENESIS INHIBITOR}

Endostatin, an angiogenesis inhibitor produced by mouse haemangioendothelioma cells, is a fragment of collagen type XVIII. ${ }^{92}$ Thus, the fact that abundant components of the circulatory system such as fibronectin and plasminogen can be converted to potent angiostatic factors suggests a new form of regulation by proteases, such as serine proteases, to specifically release these molecules from their parent molecules. There has been recent interest in endostatin therapy in models of arthritis. Nagashima and coworkers showed that endostatin levels are not increased in RA compared with OA synovial fluids. ${ }^{93}$ When these investigators administered endostatin in an RA synovial tissue-SCID chimera model, inflammation and angiogenesis were reduced in the synovium. ${ }^{36}$ Yin and coworkers used lentiviral gene therapy to deliver endostatin to TNF $\alpha$ transgenic mice, which spontaneously develop arthritis. ${ }^{94}$ Endostatin decreased mouse joint mRNA levels of a number of angiogenic factors, including VEGF and bFGF. Most cytokines that were decreased seemed to use the Jun kinase (JNK) signalling pathway.

\section{ENDOGENOUS INHIBITOR OF ANGIOGENESIS DERIVED FROM CARTILAGE}

Interestingly, cartilage is avascular as well as relatively tumour resistant. So, it is reasonable that among the earliest described inhibitors of neovascularisation were cartilage derived inhibitors. Inhibitors of angiogenesis have been purified from various types of cartilage. ${ }^{95-99}$ Shark cartilage contains a potent inhibitor of angiogenesis, accounting for its popularity in some circles as an unorthodox treatment for cancer. ${ }^{100} \mathrm{~A}$ cartilage derived inhibitor from bovine scapula has been described which is also an inhibitor of collagenase. Recently, a human cartilage derived angiogenesis inhibitor has been shown to be troponin I, a protein responsible for regulation of muscle contractions. ${ }^{95} 96$ 101 Like angiostatin, troponin I acts by binding ATPase, thus depleting energy needed for blood vessel growth. Regardless of the source, it is intriguing that cartilage, which lies in juxtaposition to the inflamed RA synovium, may hold the key to an understanding of how one might inhibit the angiogenic process in the joint.

\section{CYTOKINES AS ANGIOSTATIC AGENTS}

A number of cytokines are potential angiostatic agents. For instance, we and others have shown that IL4 is of therapeutic benefit in animal models of RA and in human RA synovial tissue explant cultures. ${ }^{102-104}$ In our hands, a portion of the mechanism of this cytokine in rat AIA is through reduction of synovial angiogenesis. ${ }^{103} 105$

Recently an inhibitor of ILl, the ILl receptor antagonist has been shown to block corneal angiogenesis in the rat. ${ }^{106}$ Moreover, this cytokine reduced the number of blood vessels and decreased arthritis in joints of rats with AIA.

\section{THALIDOMIDE AS AN ANGIOSTATIC AGENT}

Thalidomide was once marketed as a sleeping pill until it was shown to induce defective limb development in the offspring of pregnant females who ingested the drug. This defect was probably due to its ability to inhibit angiogenesis, perhaps by binding TNF $\alpha$, which is a key mediator in RA. In animal studies, it appears that thalidomide suppresses the severity of rat CIA, but not through TNF $\alpha$ or VEGF down regulation. ${ }^{107} 108$ Thalidomide decreased inflammation and numbers of blood vessels in a human RA synovial tissue-SCID chimera. ${ }^{36}$ Thalidomide has been used in two small trials in patients with refractory RA, either alone or in combination with pentoxyfilline. ${ }^{109} 110$ Although this treatment was somewhat effective, the side effect profile was considerable, with adverse reactions including drowsiness, xerostomia, and constipation.

\section{FUMIGILLIN AND ITS DERIVATIVES AS} ANGIOSTATIC AGENTS

Fumigillin is an angiostatic compound discovered as a fungal contaminant on an endothelial culture dish, which inhibited endothelial growth. ${ }^{11-114}$ Derivatives of this compound termed AGM-1470 or TNP-470 inhibit both angiogenesis and arthritis in rat AIA and CIA models, as well as in the KRN $\times$ NOD model in mice. ${ }^{39} 114115$ Interestingly, angiogenesis may also have a role in bone formation. TNP-470 inhibits ectopic bone formation induced by bone morphogenetic protein in mice. ${ }^{116}$ Fumigillin may be a potential therapeutic agent, inhibiting arthritis and angiogenesis in RA.

\section{SULFASALAZINE AS AN ANGIOSTATIC AGENT}

Sulfasalazine is commonly used in the treatment of a variety of diseases, including RA. The active metabolite of sulfasalazine may be sulfapyridine. In one study, while sulfapyridine inhibited endothelial proliferation, sulfasalazine and 5-aminosalicylic acid metabolites did not. ${ }^{117}$ We have shown that sulfasalazine and sulfapyridine reduce endothelial proliferation as well as chemotaxis. ${ }^{118}$ Sulfapyridine also inhibits phorbol myristate acetate-induced endothelial tube formation in vitro. We have also shown that sulfapyridine may mediate this effect by reducing endothelial IL8 production.

\section{OTHER ANGIOSTATIC AGENTS}

Some of the endogenous and exogenous inhibitors of angiogenesis which have been identified to date include angiostatic corticosteroids, minocycline, choloroquine, methotrexate, penicillamine, TNF $\alpha$ inhibitors, thiol-containing compounds such as gold compounds, taxol, 2-methoxyoestradiol, and cyclo-oxygenase-2 (COX-2) inhibitors.

Several angiogenesis modulating agents have recently been tried in rodent models of arthritis. These include taxol and 2-methoxyoestradiol. Taxol, a chemotherapeutic agent, inhibited CIA in rats and inhibited synovial angiogenesis. ${ }^{119}$ 2-Methoxyoestradiol treatment of CIA arthritis in mice reduced the arthritis. In vitro, this compound inhibited proliferation of endothelial cells. ${ }^{120}$

Prostaglandins, such as prostaglandin $\mathrm{E}_{2}$, are potent mediators of angiogenesis. ${ }^{121} \mathrm{COX}-2$ inhibitors are used for the treatment of RA. Not surprisingly, they have been shown to inhibit angiogenesis mainly in tumour models..$^{272-125}$ Possibly, these modulators are also effective in reducing RA angiogenesis.

\section{CAN ANGIOGENIC MARKERS HELP GUIDE TREATMENT IN RA?}

Some angiogenic markers may be useful. For instance, soluble CD146 is up regulated in synovial fluids from patients with RA compared with traumatic injury. ${ }^{60}$ Patients with early RA had the highest values of this marker in their synovial fluid. Soluble CD146 correlated significantly with the degree of morning stiffness, the number of tender joints, and the number of swollen joints.

Fraser and coworkers recently used needle arthroscopy in 34 patients, of whom 12 had early RA. They showed that synovial fluid matrix metalloproteinase 9 levels correlated with blood vessel morphology and synovial fluid VEGF levels, particularly in early RA. ${ }^{126}$ These studies indicate that angiogenic markers have the potential to help guide us in RA management.

\section{CAN ANGIOGENIC MARKERS PREDICT RA DISEASE OUTCOME?}

In a study of 44 patients, serum VEGF at presentation in patients with early RA correlated significantly with the development of radiographic damage after one year. ${ }^{127}$ This study is 
perhaps the most compelling one to depict a role for angiogenesis modulation guiding treatment for RA.

\section{WHAT CAN WE EXPECT IN ANGIOGENESIS MODULATION IN THE FUTURE?}

A new notion has developed over the recent few years that preferential endothelial precursors may exist within the population of blood stem cells. For instance, some CD $34^{+}$cells carrying receptors for VEGF may, under some circumstances, develop into endothelial cells. ${ }^{128-130}$ These cells may be important in the induction and perpetuation of angiogenesis, as well as endothelial differentiation. ${ }^{128-130}$ In addition, they may also be used for the induction of neovascularisation in future therapeutic trials in certain vascular disorders. ${ }^{131-133}$ VEGF and bFGF have been used in clinical trials to induce angiogenesis, by stimulating endothelial morphogenesis from stem cells in ischaemic heart disease, ${ }^{131}$ as well as obliterative arteriosclerosis. ${ }^{132}{ }^{133}$ The use of this technology to modulate angiogenesis has not yet been used in RA or its animal models, but may hold promise in arthritis as well.

Alternatively, one may envision a future where additional angiostatic agents are found that confer minimal toxicity when used as therapeutic agents. Other strategies may be the administration of angiostatic cytokines through genetic or viral approaches. Some targets may include receptors for angiogenic factors as the hierarchy of angiogenic and angiostatic factors in RA becomes established. Regardless of the approach, data in recent years favour the modulation of the angiogenic balance as a viable therapeutic option for RA.

\section{ACKNOWLEDGEMENTS}

Support for this work was provided by NIH grants AI40987 and HL58695, the Veteran's Administration Research Service, and the Gallagher Professorship for Arthritis Research. Apologies to those whose work was not cited owing to space limitations.

\section{Author's affiliation}

A E Koch, Feinberg School of Medicine, Northwestern University and Veteran's Administration Chicago Healthcare System, Lakeside Division, USA

Correspondence to: Dr A E Koch, Feinberg School of Medicine, Northwestern University, Ward Building 3-315, 303 E Chicago Ave, Chicago, IL 60611, USA; ae-koch@nwu.edu

\section{REFERENCES}

1 Walsh DA, Pearson $\mathrm{Cl}$. Angiogenesis in the pathogenesis of inflammatory joint and lung diseases. Arthritis Res 2001;3:147-53.

2 Walsh DA. Angiogenesis and arthritis. Rheumatology (Oxford) 1999:38:103-12.

3 Walsh DA, Haywood L. Angiogenesis: a therapeutic target in arthritis. Curr Opin Investig Drugs $2001 ; 2: 1054-63$

4 Brenchley PE. Antagonising angiogenesis in rheumatoid arthritis. Ann Rheum Dis 2001;60(suppl III):iii71-4.

5 Brenchley PEC. Angiogenesis in inflammatory joint disease: a target for therapeutic intervention. Clin Exp Immunol 2000;121:426-9.

6 Koch AE. The role of angiogenesis in rheumatoid arthritis: recent developments. Ann Rheum Dis 2000;59(suppl I):165-71.

7 Koch AE. Angiogenesis:implications for rheumatoid arthritis. Arthritis Rheum 1998:41:951-62.

8 Szekanecz Z, Koch AE. Chemokines and angiogenesis. Curr Opin Rheumatol 2001;13:202-8

9 Szekanecz Z, Szegedi G, Koch AE. Angiogenesis in rheumatoid arthritis: pathogenic and clinical significance. J Invest Med 1998:46:27-41.

10 Szekanecz Z, Halloran MM, Haskell CA, Shah MR, Polverini PJ, Koch $\mathrm{AE}$. Mediators of angiogenesis: the role of cellular adhesion molecules. Trends in Glycoscience and Glycotechnology 1999;1 1:73-93.

11 Walsh DA, Mapp PI, Wharton J, Rutherford RAD, Kidd BL, Revell PA, et al. Localization and characterization of substance $P$ binding to human synovial tissue in rheumatoid arthritis. Ann Rheum Dis 1992;51:313-17.

12 Brenchley PE. Angiogenesis in inflammatory joint disease: a target for therapeutic intervention. Clin Exp Immunol 2000;121:426-9.

13 Paleolog EM, Moitla JM. Angiogenesis in arthritis: role in disease pathogenesis and as a potential therapeutic target. Angiogen 1998;2:295-307.
14 Paleolog EM, Fava RA. Angiogenesis in rheumatoid arthritis: implications for future therapeutic strategies. Springer Semin Immunopathol 1998;20:73-94.

15 Paleolog EM. Angiogenesis: a critical process in the pathogenesis of RA - a role for VEGF? Br J Rheumatol 1996:35:917-19.

16 Folkman J, Klagsbrun M, Sasse J, Wadzinski M, Ingber D, Vlodavsky I. A heparin-binding angiogenic protein-basic fibroblast growth factor-is stored within basement membrane. Am J Pathol 1988;130:393-400.

17 Yamashita A, Yonemitsu Y, Okano S, Nakagawa K, Nakashima Y, Irisa $T$, et al. Fibroblast growth factor-2 determines severity of joint disease in adjuvant-induced arthritis in rats. J Immunol 2002;168:450-7

18 Ferrara N, Davis-Smyth T. The biology of vascular endothelial growth factor. Endocr Rev 1997; 18:4-25.

19 Ferrara N. Molecular and biological properties of vascular endothelial growth factor. J Molec Med 1999;77:527-43.

20 Ferrara $\mathbf{N}$. The role of vascular endothelial growth factor in pathological angiogenesis. Breast Cancer Res Treat 1995;36:127-37.

21 Koch AE, Harlow LA, Haines GK, Amento EP, Unemori EN, Wong WL, et al. Vascular endothelial growth factor. A cytokine modulating endothelial function in rheumatoid arthritis. J Immunol 1994;152:4149_ 56.

22 Jackson JR, Minton JA, Ho ML, Wei N, Winkler JD. Expression of vascular endothelial growth factor in synovial fibroblasts is induced by hypoxia and interleukin 1 beta. J Rheumatol 1997;24:1253-9.

23 Harada M, Mitsuyama K, Yoshida H, Sakisaka S, Taniguchi E, Kawaguchi $T$, et al. Vascular endothelial growth factor in patients with rheumatoid arthritis. Scand J Rheumatol 1998;27:377-80.

24 Fava RA, Olsen NJ, Spencer-Green G, Yeo KT, Yeo TK, Berse B, et al. Vascular permeability factor/endothelial growth factor (VPF/VEGF): accumulation and expression in human synovial fluids and rheumatoid synovial tissue. J Exp Med 1994;180:341-6.

25 Kikuchi K, Kubo M, Kadono T, Yazawa N, Ihn H, Tamaki K. Serum concentrations of vascular endothelial growth factor in collagen diseases. Br J Dermatol 1998;139:1049-51.

26 Bottomley MJ, Webb NJ, Watson CJ, Holt PJ, Freemont AJ, Brenchley PE. Peripheral blood mononuclear cells from patients with rheumatoid arthritis spontaneously secrete vascular endothelial growth factor (VEGF): specific up-regulation by tumour necrosis factor-alpha (TNF-alpha) in synovial fluid. Clin Exp Immunol 1999;117:171-6.

27 Ben-Av P, Crofford L, Wilder RL, Hla T. Induction of vascular endothelial growth factor expression in synovial fibroblasts by prostaglandin $\mathrm{E}$ and interleukin-1: a potential mechanism for inflammatory angiogenesis. FEBS Lett 1995:372:83-7.

28 Nagashima M, Yoshino S, Ishiwata T, Asano G. Role of vascular endothelial growth factor in angiogenesis of rheumatoid arthritis. Rheumatol 1995:22:1624-30.

29 Berse B, Hunt JA, Diegel R, Morganelli P, Yeo K, Brown F, et al. Hypoxia augments cytokine (transforming growth factor-beta (TGF-beta) and IL-1-induced vascular endothelial growth factor secretion by human synovial fibroblasts. Clin Exp Immunol 1999; 1 15:176-82.

30 Cho CS, Cho ML, Min SY, Kim WU, Min DJ, Lee SS, et al. CD40 engagement on synovial fibroblast up-regulates production of vascular endothelial growth factor. J Immunol 2000; 164:5055-61

31 Mason JC, Lidington EA, Yarwood H, Lublin DM, Haskard DO Induction of endothelial cell decay-accelerating factor by vascular endothelial growth factor: a mechanism for cytoprotection against complement-mediated injury during inflammatory angiogenesis. Arthritis Rheum 2001;44:138-50.

32 Paavonen K, Mandelin J, Partanen T, Jussila L, Li TF, Ristimaki A, et al. Vascular endothelial growth factors $C$ and D and their VEGFR-2 and 3 receptors in blood and lymphatic vessels in healthy and arthritic synovium. J Rheumatol 2002;29:39-45.

33 Cho ML, Cho CS, Min SY, Kim SH, Lee SS, Kim WU, et al. Cyclosporine inhibition of vascular endothelial growth factor production in rheumatoid synovial fibroblasts. Arthritis Rheum 2002;46:1202-9.

34 Paleolog EM, Young S, Stark AC, McCloskey RV, Feldmann M, Main RN. Modulation of angiogenic vascular endothelial growth factor by tumor necrosis factor alpha and interleukin-1 in rheumatoid arthritis. Arthritis Rheum 1998;41:1258-65

35 Sekimoto T, Hamada K, Oike Y, Matsuoka T, Matsumoto M, Chosa E, et al. Effect of direct angiogenesis inhibition in rheumatoid arthritis using a soluble vascular endothelial growth factor receptor 1 chimeric protein. J Rheumatol 2002;29:240-5

36 Nagashima $\mathbf{M}$, Tanaka H, Takahashi H, Tachihara A, Tanaka K, Ishiwata $T$, et al. Study of the mechanism involved in angiogenesis and synovial cell proliferation in human synovial tissues of patients with rheumatoid arthritis using SCID mice. Lab Invest 2002;82:981-8.

37 Lu J, Kasama T, Kobayashi K, Yoda Y, Shiozawa F, Hanyuda M, et al. Vascular endothelial growth factor expression and regulation of murine collagen-induced arthritis. J Immunol 2000; 164:5922-7.

38 Sone H, Kawakami Y, Sakauchi M, Nakamura Y, Takahashi A, Shimano $\mathrm{H}$, et al. Neutralization of vascular endothelial growth factor prevents collagen-induced arthritis and ameliorates established disease in mice. Biochem Biophys Res Commun 2001;281:562-8.

39 de Bandt M, Grossin M, Weber AJ, Chopin M, Elbim C, Pla M, et al. Suppression of arthritis and protection from bone destruction by treatment with TNP-470/AGM-1470 in a transgenic mouse model of rheumatoid arthritis. Arthritis Rheum 2000;43:2056-63.

40 Miotla J, Maciewicz R, Kendrew J, Feldmann M, Paleolog E. Treatment with soluble VEGF receptor reduces disease severity in murine collagen-induced arthritis. Lab Invest 2000;80: 1195-205. 
41 Luttun A, Tiwa M, Moons L, Wu Y, Angelillo-Scherrer A, Liao F, et al. Revascularization of ischemic tissues by PIGF treatment, and inhibition of tumor angiogenesis, arthritis and atherosclerosis by anti-Flt1. Nat Med 2002;8:831-40

42 Jones A, Harris AL. New developments in angiogenesis: a major mechanism for tumor growth and target for therapy. Cancer J Sci Am 1998:4:209-17.

43 Hollander AP, Corke KP, Freemont AJ, Lewis CE. Expression of hypoxia-inducible factor lalpha by macrophages in the rheumatoid synovium: implications for targeting of therapeutic genes to the inflamed joint. Arthritis Rheum 2001:44:1540-4.

44 Cramer T, Yamanishi Y, Clausen BE, Forster I, Pawlinski R, Mackman N, et al. HIF-l alpha is essential for myeloid cell-mediated inflammation. Cell 2003; 1 12:645-57

45 Park CC, Morel JC, Amin MA, Connors MA, Harlow LA, Koch AE. Evidence of IL-1 8 as a novel angiogenic mediator. J Immunol 2001;167:1644-53

46 Koch AE, Polverini PJ, Kunkel SL, Harlow LA, DiPietro LA, Elner VM, et al. Interleukin-8 as a macrophage-derived mediator of angiogenesis. Science 1992;258:1798-801

47 Strieter RM, Polverini PJ, Kunkel SL, Arenberg DA, Burdick MD, Kasper $\mathrm{J}$, et al. The functional role of the ELR motif in CXC chemokine-mediated angiogenesis. J Biol Chem 1995;270:27348-57

48 Salcedo R, Wasserman K, Young HA, Grimm MC, Howard OM, Anver $M R$, et al. Vascular endothelial growth factor and basic fibroblast growth factor induce expression of CXCR4 on human endothelial cells: in vivo neovascularization induced by stromal-derived factor-l alpha. Am J Pathol 1999:154:1125-35.

49 Hitchon C, Wong K, Ma G, Reed J, Lyttle D, El-Gabalawy H. Hypoxia-induced production of stromal cell-derived factor 1 (CXCL12) and vascular endothelial growth factor by synovial fibroblasts. Arthritis Rheum 2002:46:2587-97.

50 Nanki T, Hayashida K, El-Gabalawy HS, Suson S, Shi K, Girschick HJ, et al. Stromal cell-derived factor-1-CXC chemokine receptor 4 interactions play a central role in CD4(+) T cell accumulation in rheumatoid arthritis synovium. J Immunol 2000; 165:6590-8.

51 Blades MC, Ingegnoli F, Wheller SK, Manzo A, Wahid S, Panayi GS, et al. Stromal cell-derived factor 1 (CXCL12) induces monocyte migration into human synovium transplanted onto SCID mice. Arthritis Rheum 2002;46:824-36.

52 Volin MV, Woods JM, Amin MA, Connors MA, Harlow LA, Koch AE. Fractalkine: a novel angiogenic chemokine in rheumatoid arthritis. Am J Pathol 2001;159:1521-30.

53 Bazan JF, Bacon KB, Hardiman G, Wang W, Soo K, Rossi D, et al. A new class of membrane-bound chemokine with a CX3C motif. Nature 1997;385:640-4.

54 Johnson BA, Haines GK, Harlow LA, Koch AE. Adhesion molecule expression in human synovial tissue. Arthritis Rheum 1993;36:137-46.

55 Brooks PC, Clark RA, Cheresh DA. Requirement of vascular integrin alpha $v$ beta 3 for angiogenesis. Science 1994;264:569-71

56 Pirila L, Heino J. Altered integrin expression in rheumatoid synovial lining type $B$ cells:in vitro cytokine regulation of alpha 1 beta 1, alpha 6 beta 1, and alpha $v$ beta 5 integrins. J Rheumatol 1996;23:1691-8.

57 Storgard CM, Stupack DG, Jonczyk A, Goodman SL, Fox RI, Cheresh DA. Decreased angiogenesis and arthritic disease in rabbits treated with an alphavbeta3 antagonist. J Clin Invest 1999;103:47-54.

58 Badger AM, Blake S, Kapadia R, Sarkar S, Levin J, Swift BA, et al. Disease-modifying activity of SB 273005 , an orally active, nonpeptide alphavbeta3 (vitronectin receptor) antagonist, in rat adjuvant-induced arthritis. Arthritis Rheum 2001:44:128-37.

59 Gerlag DM, Borges E, Tak PP, Ellerby HM, Bredesen DE, Pasqualini R, et al. Suppression of murine collagen-induced arthritis by targeted apoptosis of synovial neovasculature. Arthritis Res 2001;3:357-61

60 Neidhart M, Wehrli R, Bruhlmann P, Michel BA, Gay RE, Gay S Synovial fluid CD146 (MUC 18), a marker for synovial membrane angiogenesis in rheumatoid arthritis. Arthritis Rheum 1999;42:622-30.

61 Ferrara N. Missing link in angiogenesis. Nature 1995;376:467.

62 Koch AE, Halloran MM, Haskell CJ, Shah MR, Polverini PJ. Angiogenesis mediated by soluble forms of E-selectin and vascular cell adhesion molecule-1. Nature 1995:376:517-19.

62a Kumar P, Amin MA, Harlow LA, Polverini PJ, Koch AE. Src and phosphatidylinositol 3-kinase mediate soluble E-selectin-induced angiogenesis. Blood 2003;101:3960-8.

63 Paleolog EM, Hunt M, Elliott $M$, Feldmann M, Maini RN, Woody JN. Deactivation of vascular endothelium by monoclonal anti-tumor necrosis factor alpha antibody in rheumatoid arthritis. Arthritis Rheum 1996;39:1082-91

64 Halloran MM, Carley WW, Polverini PJ, Haskell CJ, Phan S, Anderson $\mathrm{BJ}$, et al. Ley/H: an endothelial-selective, cytokine-inducible, angiogenic mediator. J Immunol 2000; 164:4868-77.

65 Holgersson J, Breimer ME, Samuelsson BE. Basic biochemistry of cell surface carbohydrates and aspects of the tissue distribution of histo-blood group $\mathrm{ABH}$ and related glycosphingolipids. Apmis Suppl 1992;27:18-27

66 Appelmelk BJ, Simoons-Smit I, Negrini R, Moran AP, Aspinall GO, Forte JG, et al. Potential role of molecular mimicry between Helicobacter pylori lipopolysaccharide and host Lewis blood group antigens in autoimmunity. Infect Immun 1996;64:2031-40.

67 Aspinall GO, Monteiro MA. Lipopolysaccharides of Helicobacter pylor strains P466 and MO19: structures of the $\mathrm{O}$ antigen and core oligosaccharide regions. Biochemistry 1996;35:2498-504.

68 Hanahan D, Folkman J. Patterns and emerging mechanisms of the angiogenic switch during tumorigenesis. Cell 1996;86:353-64.
69 Hohenester E, Sasaki T, Olsen BR, Timpl R. Crystal structure of the angiogenesis inhibitor endostatin at $1.5 \mathrm{~A}$ resolution. Embo J 1998; 17:1656-64

70 Davis S, Aldrich TH, Jones PF, Acheson A, Compton DL, Jain V, et al. Isolation of angiopoietin-1, a ligand for the TIE2 receptor, by secretion-trap expression cloning. Cell 1996:87:1161-9.

71 Folkman J, D'Amore PA. Blood vessel formation: what is its molecular basis? Cell 1996;87:1 153-5

72 Suri C, Jones PF, Patan S, Bartunkova S, Maisonpierre PC, Davis S, et al. Requisite role of angiopoietin-1, a ligand for the TIE2 receptor, during embryonic angiogenesis. Cell 1996:87:1171-80.

73 Shahrara S, Volin MV, Connors MA, Haines GK, Koch AE. Differential expression of the angiogenic Tie receptor family in arthritic and normal synovial tissue. Arthritis Res 2002;4:201-8

74 Gravallese EM, Pettit AR, Lee R, Madore R, Manning C, Tsay A, et al. Angiopoietin-1 is expressed in the synovium of patients with rheumatoid arthritis and is induced by tumour necrosis factor alpha. Ann Rheum Dis 2003:62:100-7.

75 Vikkula $M$, Boon LM, Carraway KL, Calvert JT, Diamonti AJ, Goumnerov $B$, et al. Vascular dysmorphogenesis caused by an activating mutation in the receptor kinase TIE2. Cell 1996:87:1 153-5.

76 Uchida T, Nakashima M, Hirota Y, Miyazaki Y, Tsukazaki T, Shindo H. Immunohistochemical localisation of protein tyrosine kinase receptors Tie- 1 and Tie-2 in synovial tissue of rheumatoid arthritis:correlation with angiogenesis and synovial proliferation. Ann Rheum Dis 2000:59:607-14

77 Homandberg GA, Williams JE, Grant D, Schumacher B, Eisenstein R. Heparin-binding fragments of fibronectin are potent inhibitors of endothelial cell growth. Am J Pathol 1985;120:327-32.

78 O'Reilly MS, Holmgren L, Shing Y, Chen C, Rosenthal RA, Moses M, et al. Angiostatin: a novel angiogenesis inhibitor that mediates the suppression of metastases by a lewis lung carcinoma. Cell 1994:79:315-28.

79 Clapp C, Martial JA, Guzman RC, Rentier-Delure F, Weiner RI. The 16-kilodalton $\mathrm{N}$-terminal fragment of human prolactin is a potent inhibitor of angiogenesis. Endocrinology 1993;133:1292-9.

80 Ferrara N, Clapp C, Weiner R. The 16K fragment of prolactin specifically inhibits basal or fibroblast growth factor stimulated growth of capillary endothelial cells. Endocrinology 1991;129:896-900.

81 Good DJ, Polverini PJ, Rastinejad F, Le Beau MM, Lemons RS, Frazier WA, et al. A tumor suppressor-dependent inhibitor of angiogenesis is immunologically and functionally indistinguishable from a fragment of thrombospondin. Proc Natl Acad Sci USA 1990;87:6624-8.

82 Jimenez B, Volpert OV, Crawford SE, Febbraio M, Silverstein RL, Bouck $N$. Signals leading to apoptosis-dependent inhibition of neovascularization by thrombospondin-1. Nat Med 2000;6:41-8.

83 Vazquez F, Hastings G, Ortega MA, Lane TF, Oikemus S, Lombardo M, et al. METH-1, a human ortholog of ADAMTS-1, and METH-2 are members of a new family of proteins with angio-inhibitory activity. J Biol Chem 1999;274:23349-57.

84 Koch AE, Szekanecz Z, Friedman J, Haines GK, Langman CB, Bouck NP. Effects of thrombospondin-1 on disease course and angiogenesis in rat adjuvant-induced arthritis. Clin Immunol Immunopatho 1998;86:199-208

85 Gately S, Twardowski P, Stack MS, Patrick M, Boggio L, Cundiff DL, et al. Human prostate carcinoma cells express enzymatic activity that converts human plasminogen to the angiogenesis inhibitor, angiostatin. Cancer Res 1996;56:4887-90.

86 Cao Y, Ji RW, Davidson D, Schaller J, Marti D, Sohndel S, et al. Kringle domains of human angiostatin. Characterization of the anti-proliferative activity on endothelial cells. J Biol Chem 1996:271:29461-7.

87 O'Reilly MS, Holmgren L, Chen C, Folkman J. Angiostatin induces and sustains dormancy of human primary tumors in mice. Nat Med 1996;2:689-92.

88 Holmgren L, O'Reilly MS, Folkman J. Dormancy of micrometastases: balanced proliferation and apoptosis in the presence of angiogenesis suppression. Nat Med 1995;1:149-53

89 Moser TL, Stack MS, Asplin I, Enghild JJ, Hojrup P, Everitt L, et al. Angiostatin binds ATP synthase on the surface of human endothelial cells. Proc Natl Acad Sci USA 1999;96:2811-16.

90 Claesson-Welsh L, Welsh M, Ito N, Anand-Apte B, Soker S, Zetter B, et al. Angiostatin induces endothelial cell apoptosis and activation of focal adhesion kinase independently of the integrin-binding motif RGD. Proc Natl Acad Sci USA 1998;95:5579-83.

91 Kim JM, Ho SH, Park EJ, Hahn W, Cho H, Jeong JG, et al. Angiostatin gene transfer as an effective treatment strategy in murine collagen-induced arthritis. Arthritis Rheum 2002;46:793-801.

92 O'Reilly MS, Boehm T, Shing Y, Fukai N, Vasios G, Lane WS, et al. Endostatin: an endogenous inhibitor of angiogenesis and tumor growth. Cell 1997:88:277-85.

93 Nagashima M, Asano G, Yoshino S. Imbalance in production between vascular endothelial growth factor and endostatin in patients with rheumatoid arthritis. J Rheumatol 2000;27:2339-42.

94 Yin G, Liu W, An P, Li P, Ding I, Planelles V, et al. Endostatin gene transfer inhibits joint angiogenesis and pannus formation in inflammatory arthritis. Mol Ther 2002:5:547-54

95 Moses MA, Sudhalter J, Langer R. Identification of an inhibitor of neovascularization from cartilage. Science 1990;248:1408-10. 96 Moses MA. A cartilage-derived inhibitor of neovascularization and metalloproteinases. Clin Exp Rheumatol 1993;11(suppl 8):S67-9.

97 Kuettner KE, Pauli BU. Inhibition of neovascularization by a cartilage factor. Ciba Found Symp 1983; 100:163-73. 
98 Brem H, Folkman J. Inhibition of tumor angiogenesis mediated by cartilage. J Exp Med 1975;141:427-39.

99 Langer $\mathbf{R}$, Brem H, Falterman K, Klein M, Folkman J. Isolation of a cartilage factor that inhibits tumor neovascularization. Science 1976:193:70-2.

100 Lee A, Langer R. Shark cartilage contains inhibitors of tumor angiogenesis. Science 1983;221:1185-7.

101 Moses MA, Wiederschain D, Wu I, Fernandez CA, Ghazizdeh V, Lane WS, et al. Troponin I is present in human cartilage and inhibits angiogenesis. Proc Natl Acad Sci USA 1999;96:2645-50.

102 Moissec P, Briolay J, Dechanet J, Wijdenes J, Martinez-Valdez H, Banchereau J. Inhibition of the production of proinflammatory cytokines and immunoglobulins by interleukin- 4 in an ex vivo model of rheumatoid synovitis. Arthritis Rheum 1992;35:874-83.

103 Woods JM, Katschke KJ Jr, Volin MV, Ruth JH, Woodruff DC, Amin MA et al. IL-4 adenoviral gene therapy reduces inflammation, proinflammatory cytokines, vascularization, and bony destruction in rat adjuvant-induced arthritis. J Immunol 2001; 166:1214-22.

104 Woods JM, Tokuhira M, Berry JC, Katshke KJ Jr, Kurata H, Damergis JA $\mathrm{Jr}$, et al. Interleukin-4 adenoviral gene therapy reduces production of inflammatory cytokines and prostaglandin E2 by rheumatoid arthritis synovium ex vivo. J Investig Med 1999;47:285-92.

105 Volpert OV, Fong T, Koch AE, Peterson JD, Waltenbaugh C, Tepper RI, et al. Inhibition of angiogenesis by interleukin 4. J Exp Med 1998; 188:1039-46.

106 Coxon A, Bolon B, Estrada J, Kaufman S, Scully S, Rattan A, et al. Inhibition of interleukin-1 but not tumor necrosis factor suppresses neovascularization in rat models of corneal angiogenesis and adjuvant arthritis. Arthritis Rheum 2002;46:2604-12

107 Oliver SJ, Cheng TP, Banquerigo ML, Brahn E. Suppression of collagen-induced arthritis by an angiogenesis inhibitor, AGM-1470, in combination with cyclosporin:reduction of vascular endothelial growth factor (VEGF). Cell Immunol 1995; 166:196-206.

108 Hauschild A, Kroeger $\mathrm{H}$, Mitchison NA, Ugrinovic S, Zwingenberger $\mathrm{K}$ Thalidomide therapy of established collagen-induced arthritis $(\mathrm{CIA})$ not accompanied by an evident Th2 shift. Clin Exp Immunol 1997; 108:428-31.

109 Gutierrez-Rodriguez O, Starusta-Bacal P, Gutierrez-Montes O. Treatment of refractory rheumatoid arthritis - the thalidomide experience. J Rheumatol 1989; 16:158-63

110 Huizinga TW, Dijkmans BA, van der Velde EA, van de Pouw Kraan TC, Verweii CL, Breedveld FC. An open study of pentoxyfylline and thalidomide as adjuvant therapy in the treatment of rheumatoid arthritis. Ann Rheum Dis 1996:55:833-6.

111 Kusaka M, Sudo K, Fujita T, Marui S, Itoh F, Ingber D, et al. Potent anti-angiogenic action of $A G M-1470$ :comparison to the fumagillin parent. Biochem Biophys Res Commun 1991;174:1070-6.

112 Antoine N, Greimers R, De Roanne C, Kusaka M, Heinen E, Simar L, et al. AGM-1470, a potent angiogenesis inhibitor, prevents the entry of normal but not transformed endothelial cells into the G1 phase of the cell cycle. Cancer Res 1994;54:2073-6.

113 Kusaka M, Sudo K, Matsutani E, Kozai Y, Marui S, Fujita T, et al Cytostatic inhibition of endothelial cell growth by the angiogenesis inhibitor TNP-470 (AGM-1470). Br J Cancer 1994;69:212-16.

114 Peacock DJ, Banquerigo ML, Brahn E. Angiogenesis inhibition suppresses collagen arthritis. J Exp Med 1992;175:1135-8.

115 Peacock DJ, Banquerigo ML, Brahn E. A novel angiogenesis inhibitor suppresses rat adjuvant arthritis. Cell Immunol 1995;160:178-84.

116 Mori S, Yoshikawa H, Hashimoto J, Ueda T, Funai H, Kato M, et al. Antiangiogenic agent (TNP-470) inhibition of ectopic bone formation induced by bone morphogenetic protein-2. Bone 1998;22:99-105.
117 Madhok R, Wijelath E, Smith J, Watson J, Sturrock RD, Capell HA. Is the beneficial effect of sulfasalazine due to inhibition of synovial neovascularization? J Rheumatol 1991;18:199-202.

118 Volin MV, Harlow LA, Woods JM, Campbell PL, Amin MA, Tokuhira M, et al. Treatment with sulfasalazine or sulfapyridine, but not 5-aminosalicyclic acid, inhibits basic fibroblast growth factor-induced endothelial cell chemotaxis. Arthritis Rheum 1999;42:1927-35.

119 Arsenault AL, Lhotak S, Hunter WL, Banquerigo ML, Brahn E. Taxo involution of collagen-induced arthritis: ultrastructural correlation with the inhibition of synovitis and neovascularization. Clin Immunol Immunopathol 1998;86:280-9.

120 Josefsson E, Tarkowski A. Suppression of type II collagen-induced arthritis by the endogenous estrogen metabolite 2-methoxyestradiol. Arthritis Rheum 1997;40:154-63.

121 Ziche $\mathbf{M}$, Jones J, Gullino PM. Role of prostaglandin E1 and copper in angiogenesis. J Natl Cancer Inst 1982;69:475-82.

122 Hla T, Ristimaki A, Appleby S, Barriocanal JG. Cyclooxygenase gene expression in inflammation and angiogenesis. Ann N Y Acad Sci 1993:696:197-204.

123 Majima M, Isono M, Ikeda Y, Hayashi I, Hatanaka K, Harada Y, et al. Significant roles of inducible cyclooxygenase (COX)-2 in angiogenesis in rat sponge implants. Jpn J Pharmacol 1997;75:105-14.

124 Tsujii M, Kawano S, Tsuji S, Sawaoka H, Hori M, DuBois RN. Cyclooxygenase regulates angiogenesis induced by colon cancer cells. Cell 1998;93:705-16.

125 Daniel TO Liu $\mathrm{H}$, Morrow JD, Crews BC, Marnett U. Thromboxane A2 is a mediator of cyclooxygenase-2-dependent endothelial migration and angiogenesis. Cancer Res 1999;59:4574-7.

126 Fraser A, Fearon U, Reece R, Emery P, Veale DJ. Matrix metalloproteinase 9, apoptosis, and vascular morphology in early arthritis. Arthritis Rheum 2001;44:2024-8.

127 Ballara S, Taylor PC, Reusch P, Marme D, Feldmann M, Maini RN, et al Raised serum vascular endothelial growth factor levels are associated with destructive change in inflammatory arthritis. Arthritis Rheum 2001;44:2055-64

128 Peichev M, Naiyer AJ, Pereira D, Zhu Z, Lane WJ, Williams $M$, et al. Expression of VEGFR-2 and AC133 by circulating human CD34(+) cells identifies a population of functional endothelial precursors. Blood 2000;95:952-8.

129 Gehling UM, Ergun S, Schumacher U, Wagener C, Pantel K, Otte M, et al. In vitro differentiation of endothelial cells from AC133-positive progenitor cells. Blood 2000;95:3106-12.

130 Eichmann A, Corbel C, Nataf V, Vaigot P, Breant C, Le Douarin NM. Ligand-dependent development of the endothelial and hemopoietic lineages from embryonic mesodermal cells expressing vascular endothelial growth factor receptor 2. Proc Natl Acad Sci USA 1997; $94: 5141-6$

131 Freedman SB, Isner JM. Therapeutic angiogenesis for ischemic cardiovascular disease. J Mol Cell Cardiol 2001:33:379-93.

132 Shyu KG, Manor O, Magner M, Yancopoulos GD, Isner JM. Direct intramuscular injection of plasmid DNA encoding angiopoietin-1 but not angiopoietin-2 augments revascularization in the rabbit ischemic hindlimb. Circulation 1998;98:2081-7.

133 Isner JM, Baumgartner I, Rauh G, Schainfeld R, Blair R, Manor O, et al. Treatment of thromboangiitis obliterans (Buerger's disease) by intramuscular gene transfer of vascular endothelial growth factor:preliminary clinical results. J Vasc Surg 1998;28:964-73 discussion 73-5. 